\title{
Application of Interpretative Structural Modeling (ISM) to determine port waste management strategies for African Swine Fever (ASF) prevention at Tanjung Priok Port
}

\author{
Novera Nirmalasanti ${ }^{a}$, Hefni Effendi ${ }^{b}$, Ririn Setyowati ${ }^{\mathrm{c}}$

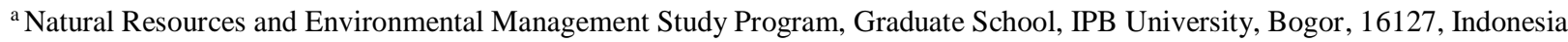 \\ [+62 811979321] \\ ${ }^{\mathrm{b}}$ Environmental Research Center, IPB University, Bogor, 16680, Indonesia [+62 81319515242] \\ ${ }^{\mathrm{c}}$ Indonesia Agricultural Quarantine Agency, Ministry of Agriculture, E-Building, Jakarta, Indonesia \\ [+62 81253790113]
}

\section{Article Info:}

Received: 03 - 11 - 2021

Accepted: $07-12-2021$

Keywords:

African Swine Fever (ASF), ISM, ships garbage, strategies

Corresponding Author:

Novera Nirmalasanti Natural Resources and Environmental Management Study Program, Graduate School, IPB University;

Tel. +62811979321

Email:

noveranirmalasanti@apps.ipb.ac. id

\begin{abstract}
African Swine Fever (ASF) is a type of animal disease in pigs caused by a virus with a high mortality rate and is highly contagious. Disease transmission occurs directly through contact with infectious animals and indirectly through feed, virus-contaminated objects, and swill feeding produced by ships. Tanjung Priok Port has many ships originating or transiting in countries infected with ASF by lowering their food waste without further processing. Among those ships, some discharge their garbage and take over into the final dumping site without any further treatment. There are many institutions and stakeholders involved in garbage management in the port of Tanjung Priok. The purpose of this study was to identify the obstacle, actors, and strategies for ship waste management to prevent the spread of ASF Virus at Tanjung Priok Port using the Interpretative Structural Modeling (ISM) method. The results showed that the most influential obstacle to ship waste management to prevent the spread of the ASF virus was the availability of Standard Operational Procedure (SOP), the actor who played the most role was PT Pelindo II and the most important strategy is to develop an integrated SOP for ship waste management.
\end{abstract}

How to cite (CSE Style $8^{\text {th }}$ Edition):

Nirmalasanti N, Effendi H, Setyowati R. 2021. Application of Interpretative Structural Modeling (ISM) to determine port waste management strategies for African Swine Fever (ASF) prevention at Tanjung Priok Port. JPSL 11(4): 532-541. http://dx.doi.org/10.29244/jpsl.11.4.532-541.

\section{INTRODUCTION}

The ASF virus outbreak first occurred in Southeast Asia, namely in China, and then spread to Mongolia, Vietnam, North Korea, Cambodia, Hong Kong, the Philippines, South Korea, and Timor Leste (OIE, 2019). Epidemiological studies of 68 ASF outbreaks in China show that there are three leading causes of the spread of ASF virus, namely $46 \%$ from vehicles and workers without disinfection, $34 \%$ from swill feeding, and $19 \%$ from the transportation of live pigs and their products between regions (FAO, 2019). Swill feeding is the provision of food waste to livestock.

Indonesia has a reasonably significant potential for pig farming, namely 8922654 heads (BPS, 2019) that need to be maintained and close to the outbreak country. In 2018 Indonesia exported 271000 pigs to Singapore with an economic value of one trillion rupiahs (BPS, 2019). Tanjung Priok Port is the busiest port of import traffic in Indonesia. There were 204 ships from epidemic countries that berthed at Tanjung Priok out of 742 
ships berthing in May-December 2019 (Pelindo, 2020). The Decree of the Minister of Agriculture of the Republic of Indonesia No. 820/KPTS/PK.320M/12/2019 stated that ASF infection occurred in North Sumatra, and it is still necessary to prevent the entry and spread of ASF carrier media from infected areas. At the regional meeting of the Ministry of Agriculture with Office International des Epizooties (OIE) it was stated that the incidence of ASF outbreaks in Indonesia also occurred in Riau in November, Padang and Bali in December 2019, East Nusa Tenggara in January, Palembang in May, Lampung in June and Central Java in August 2020.

According to Law No. 18 of 2008 concerning Waste Management, waste is the remainder of daily human activities and or natural processes in solid form. The garbage from the ship there is unloaded and not unloaded for ship waste that is not unloaded in accordance with Marine Pollution 73/78 (MARPOL 73/78) concerning Prevention of Pollution from Ships. Disposal of food waste into the sea can be permitted if it has passed a crusher or chopper located on the bridge fixed or floating placed $>12$ nautical miles from the mainland and all other ships while sailing or at a distance of $500 \mathrm{~m}$ from the bridge. Garbage unloaded from ships refers to the Regulation of the State Minister of the Environment No. 05 of 2009 concerning Waste Management in Ports article 3 paragraph (1) that ship owners or ship operators can submit waste originating from routine ship operational activities to the manager.

Food waste of animal origin originating from the arrival of foreign ships can pose a risk of disease entry into Indonesia and cause economic and industrial losses, including foot and mouth disease, African Swine Fever (ASF), Hog Cholera, and African Horse Sickness. The government will spend significant funds to handle ASF cases, and there is a ban on exporting pigs and their products abroad. Tanjung Priok Port needs to have the right strategy in international waste management, especially ship food waste, to break the chain of ASF distribution. This study aims to identify constraints, actors, and strategies in ship waste management to prevent the spread of ASF.

\section{METHOD}

\section{Research Location and Time}

The research was carried out at Tanjung Priok Port in collaboration with the Tanjung Priok Agricultural Quarantine. This research took place from January-May 2021.

\section{Method of Collecting Data}

Data collection was obtained through Focus Group Discussion (FGD), field observations and in-depth interviews, expert opinions from animal quarantine, environment, livestock socio-economics, port operational management, port authorities, business actors, and libraries and reports, documents from authorized agencies.

\section{Data Analysis Method}

This study uses the Interpretative Structural Modeling (ISM) method to see a complex problem that occurs in a system and is designed using graphics and sentences (Eriyatno, 1996). ISM is also used to assess the causes and strategies for anticipating conversions (Santoso et al., 2017). The final results of the ISM technique are key elements, structure diagrams, and Driver Power-Dependence (DP-D) matrices that describe the classification of sub-elements, namely:

1. Weak driver-weak dependent variables (Autonomous), sub-elements unrelated to the system, have a slight but strong relationship (Sector I).

2. Weak driver-strongly dependent variables (Dependent), variables are not independent and are affected by other sector programs (Sector II).

3. Strong driver-strongly dependent variables (Linkage), the variables are studied carefully because the relationship between variables is not stable. Each action on variable impacts the others, and feedback can amplify the effect (Sector III). 
4. Strong drive-weak dependent variables (Independent) have a significant driving force on the program's success but are slightly dependent on the program (Sector IV).

\section{RESULTS AND DISCUSSION}

\section{Ship Traffic and Ship Garbage}

Ship that berth at Tanjung Priok come from all over the world, in January-May 2021 there were 1328 ships as shown in Figure 1 (Pelindo, 2019). In five months, there were 419 ships originating and/or transiting from ASF outbreak countries (31.56\%). The ASF outbreak countries are China, the Philippines, Vietnam, South Korea, North Korea, Hong Kong, and Taiwan (OIE, 2019). It can be seen from Figure 2 that the largest number of ships berthed from and/or transited in China (298 ships), as it is known that China was the country where ASF outbreak occurred for the first time (OIE, 2019). There is a very large potential for the spread of ASF through ships originating from or transiting from an outbreak country to Tanjung Priok Port.

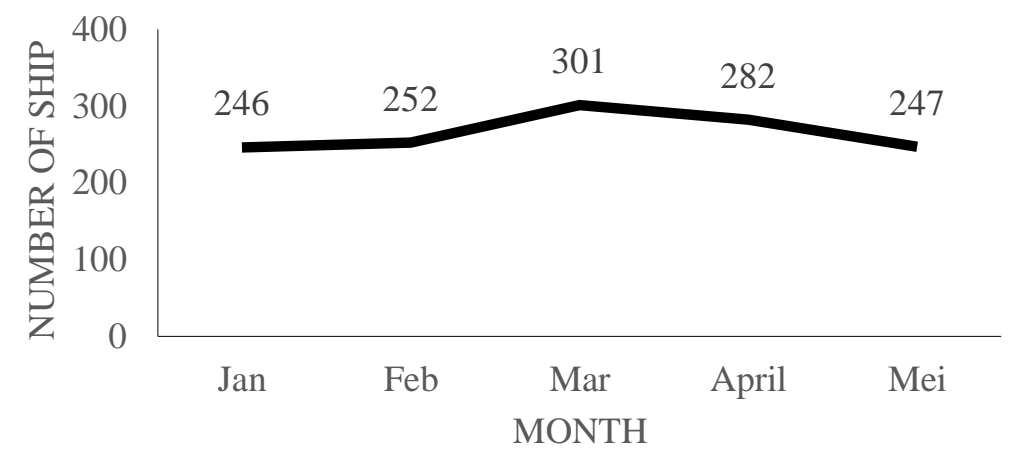

Figure 1 Number of ship berth in january-may 2021

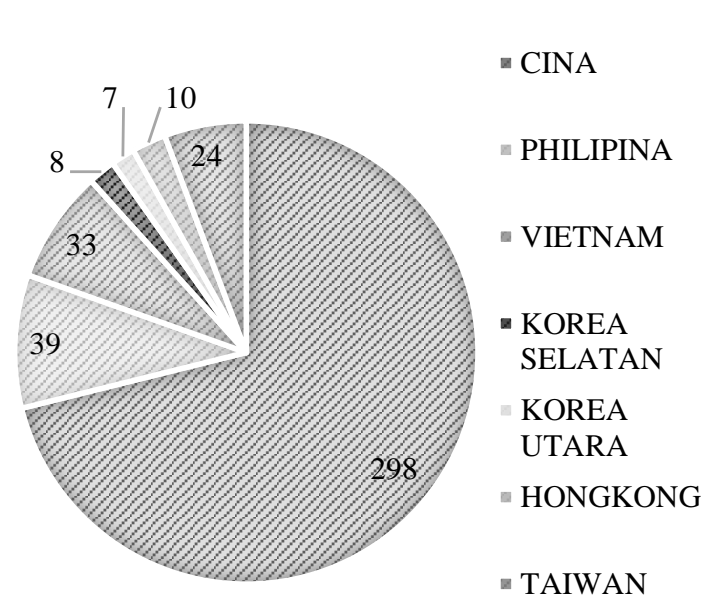

Figure 2 Ship traffic from asf outbreak countries for january-may 2021

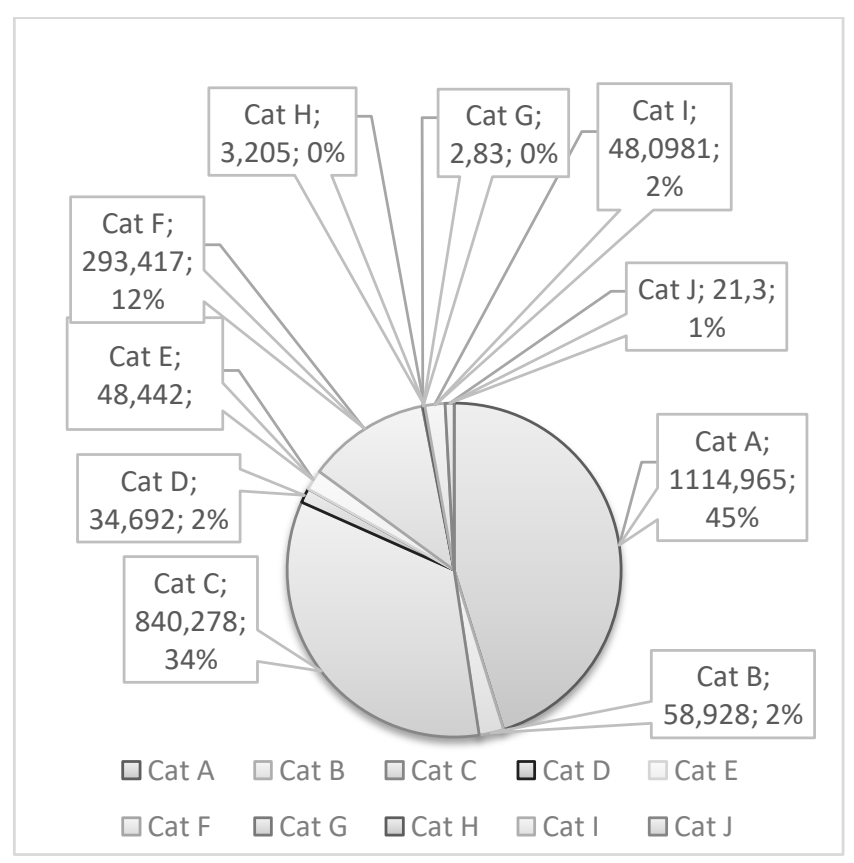

Figure 3 Amount and types of shipwreck unloaded january-may 2021 
The International Maritime Organization (IMO) defines food waste as perishable food or non-perishable parts of food, including fruits, vegetables, dairy products, poultry, meat products, and food waste produced onboard ships. Food waste is generated from vessels originating from kitchens and/or restaurants (EMSA, 2017). Based on waste certificate data, for the period January-May 2021, the total amount of ship waste that was unloaded at Tanjung Priok Port was $2466.16 \mathrm{~m}^{3}$ with the types of waste in the form of plastic (Cat A), food waste (Cat B), household waste (Cat C), cooking oil (Cat D), incinerator ash (Cat E), operational waste (Cat F), cargo residue (Cat G), animal carcasses (Cat H) and fishing gear (Cat I) (MARPOL 73/78) (Figure 3).

Food waste that can contain ASF genetics is recorded at $58928 \mathrm{~m}^{3}$, meaning an average of 0.04 $\mathrm{m}^{3} / \mathrm{ship} /$ day that is unloaded from the ship. According to EMSA (2017) food waste generated by international cargo ship crews is $0.01-0.016 \mathrm{~m}^{3} /$ person/day or $0.3 \mathrm{~kg} / \mathrm{person} / \mathrm{day}$. The number of cargo ship crews consists of 20-30 people per ship. The volume of food waste that was lowered was not too much, but given that indirect transmission occurs through feed or other objects contaminated with the ASF virus (fomites) such as clothing, shoes, vehicles, knives, equipment, and contaminated people (CFSPH, 2019).

\section{Ship Waste Management}

The flow of ship waste management at Tanjung Priok Port is that every ship that will dock must report the type and amount of waste on board no later than 48 hours before arriving through the Inaportnet Port Waste Management System (PWMS). After verification by the Main Harbormaster, the port business entity carries out ship waste collection activities (PT Balong Mas Utama and CV Harapan Kita). The unloaded waste is put in black plastic bags, collected in a transport truck, and headed to the Temporary Shelter (TPS) in Rawa Badak and Cilincing. Waste at the TPS will be sorted according to the waste category, namely inorganic waste that is still economically valuable and organic/food waste and then disposed of to the Integrated Waste Management Site (TPST) in Bantar Gebang, Bekasi to be used as compost, plastic waste is used as raw material for a plastic cement factory or burned.

\section{Ship's Waste Management Obstacle}

There are many obstacles faced by managers in the context of preventing the spread of ASF, according to ship waste management flow. With the ISM stages, (Figures 4, 5, 6) show that the availability of ship waste management SOPs and the availability of PRF are in the independent sector (Strong Drive-Weak Dependent Variables) meaning that both as key sub elements have a large driving force for the success of ship waste management but are slightly dependent on the program (Figure 7 and 8). SOP is a guideline in carrying out tasks according to the function and as a tool for assessing the performance of government and non-government agencies (Atmoko, 2011). PRF are all fixed, floating, or mobile facilities capable of receiving marine pollutant waste/garbage from ships (KemenLH, 2009). Currently, the available SOPs and PRFs are only for hazardous and toxic waste (B3 waste). Food waste is allowed to be sent to a port waste collection facility or PRF if disposal at sea is not permitted due to regulations or because the ship does not have a commuter/garbage shredder. The existence of this provision requires ports to develop plans and provide adequate waste management facilities and equipment for receiving waste (IMO, 2006).

Incinerator is a combustion furnace to treat solid waste, which converts solid material (garbage) into the gaseous matter, and ash (bottom ash and fly ash) (Defra, 2007). This method is very appropriate for handling waste containing certain viruses from a disease so that the virus can be ascertained to be dead and will not be contagious (Alcrudo et al., 2019). The presence of an incinerator depends on the ship's route, duration of voyage, onboard waste storage capacity and/or the ship's overall waste management policy (EMSA, 2017).

Given the nature of the ASF virus persisting in blood stored at $4^{\circ} \mathrm{C}$ for 18 months, in decomposing blood for 15 weeks (EFSA, 2014), it is highly likely that contamination will occur in other types of shipwreck. Arimurti et al. (2021) said that $8.69 \%(2 / 23)$ of food waste samples were taken from international ships 
originating or transiting from ASF-infected countries that were unloaded at Tanjung Priok Port were positive for the ASF virus. The positive samples came from Chinese and Philippine ships.

\begin{tabular}{|c|c|c|c|c|}
\hline & A1 & A2 & A3 & A4 \\
\hline A1 & 1 & 1 & 1 & 1 \\
\hline A2 & 0 & 1 & 1 & 1 \\
\hline A3 & 0 & 0 & 1 & 0 \\
\hline A4 & 0 & 0 & 1 & 1 \\
\hline
\end{tabular}

\begin{tabular}{|c|c|c|c|c|}
\hline & A1 & A2 & A3 & A4 \\
\hline A1 & & V & V & V \\
\hline A2 & & & V & V \\
\hline A3 & & & & A \\
\hline A4 & & & & \\
\hline
\end{tabular}

Figure 4 Self Structural Interaction Matrix (SSIM) of obstacle elements

Figure 5 Reachability matrix of obstacle elements

\begin{tabular}{|c|c|c|c|c|c|c|}
\hline & A1 & A2 & A3 & A4 & DP & R \\
\hline A1 & 1 & 1 & 1 & 1 & 4 & 1 \\
\hline A2 & 0 & 1 & 1 & 1 & 3 & 2 \\
\hline A3 & 0 & 0 & 1 & 0 & 1 & 4 \\
\hline A4 & 0 & 0 & 1 & 1 & 2 & 3 \\
\hline DP & 1 & 2 & 4 & 3 & & \\
\hline L & 4 & 3 & 1 & 2 & & \\
\hline
\end{tabular}

Obstacle

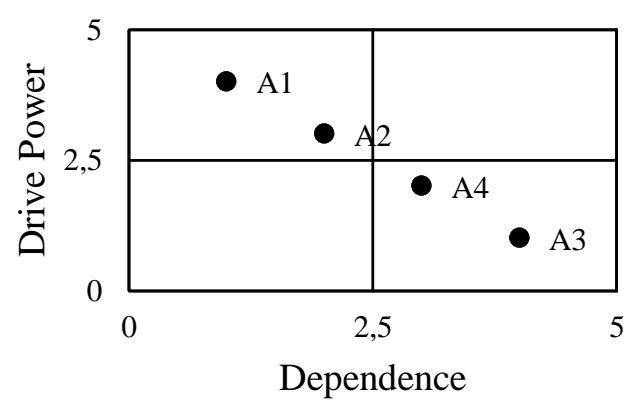

Figure 6 Final matrix of obstacle elements

Figure 7 Driver Power-Dependence (DP-D) matrix of obstacle

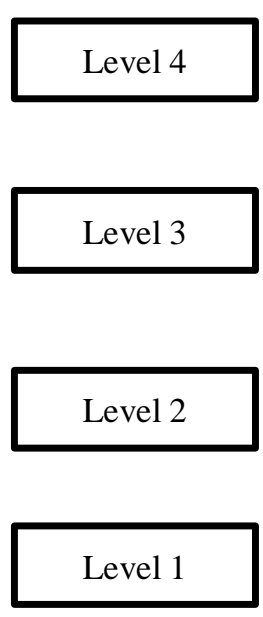

A3. Availability of incinerators on board

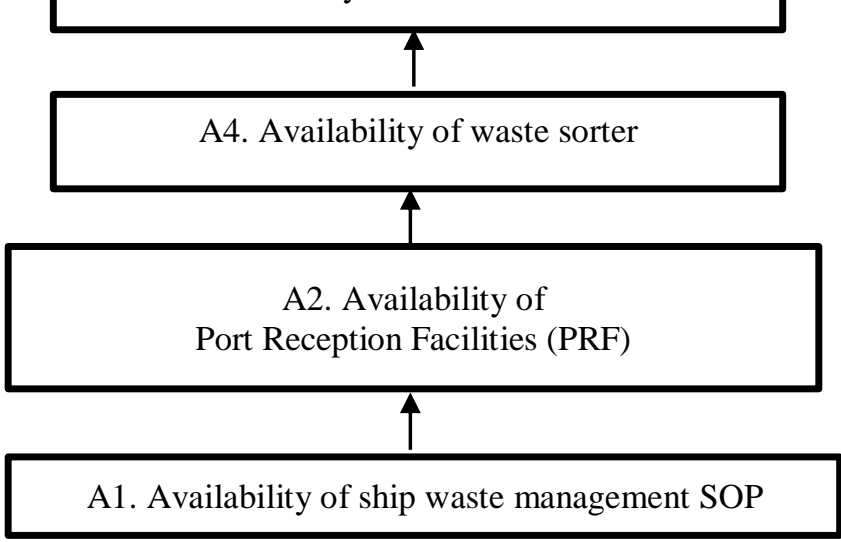

Figure 8 Hierarchy of shipwreck management obstacle 


\section{Ship Waste Management Actors}

The implementation of ship waste management and supervision also involves many actors, creating an imbalance of duties and responsibilities in the system and the field. ISM solves the problem of interrelationships and elements that are directly and indirectly related to complex organizational issues (Warfield, 2005). The ISM analysis obtained a structural interaction matrix, as shown in Figure 9-11. Figure 12 shows that Indonesia Port Corporation II and the Port Authority are included in the independent sector (Strong drive-weak dependent variables). Indonesia Port Corporation II is the actor who plays the most/dominant role because it is the operational executor in waste and waste management (Figure 13). The Port Authority, with the main tasks and functions in accordance with Law 18 of 2008 is to provide land and waters, provide and maintain shipping navigational aids, guarantee and maintain environmental sustainability in ports. Business entities/waste managers, DKI Jakarta Environmental Agency, Agricultural Quarantine, and Main Harbormasters are in quadrant II, and these actors are Weak driver variables-strongly dependent variables. The three actors have the same role in ship waste management to prevent the spread of ASF in Tanjung Priok Port. Agricultural Quarantine carries out duties in accordance with Indonesian Government Law Number 21 of 2019, in waste management, being responsible for monitoring quarantine waste at airports or seaports.

\begin{tabular}{|c|c|c|c|c|c|c|c|}
\hline & B1 & B2 & B3 & B4 & B5 & B6 & B7 \\
\hline B1 & & A & V & V & V & V & A \\
\hline B2 & & & V & V & V & V & V \\
\hline B3 & & & & V & A & V & A \\
\hline B4 & & & & & V & V & V \\
\hline B5 & & & & & & V & V \\
\hline B6 & & & & & & & A \\
\hline B7 & & & & & & & \\
\hline
\end{tabular}

Figure 9 Self Structural Interaction Matrix (SSIM) of actors elements

\begin{tabular}{|l|l|l|l|l|l|l|l|l|l|}
\hline & B1 & B2 & B3 & B4 & B5 & B6 & B7 & DP & R \\
\hline B1 & 1 & 0 & 1 & 1 & 1 & 1 & 0 & 5 & 2 \\
\hline B2 & 1 & 1 & 1 & 1 & 1 & 1 & 1 & 7 & 1 \\
\hline B3 & 0 & 0 & 1 & 1 & 0 & 1 & 0 & 3 & 4 \\
\hline B4 & 0 & 0 & 0 & 1 & 1 & 1 & 1 & 4 & 3 \\
\hline B5 & 0 & 0 & 1 & 0 & 1 & 1 & 1 & 4 & 3 \\
\hline B6 & 0 & 0 & 0 & 0 & 0 & 1 & 0 & 1 & 5 \\
\hline B7 & 1 & 0 & 1 & 0 & 0 & 1 & 1 & 4 & 3 \\
\hline DP & 3 & 1 & 5 & 4 & 4 & 7 & 4 & & \\
\hline L & 4 & 5 & 2 & 3 & 3 & 1 & 3 & & \\
\hline
\end{tabular}

Figure 11 Final reachability matrix of actors elements

\begin{tabular}{|l|l|l|l|l|l|l|l|}
\hline & B1 & B2 & B3 & B4 & B5 & B6 & B7 \\
\hline B1 & 1 & 0 & 1 & 1 & 1 & 1 & 0 \\
\hline B2 & 1 & 1 & 1 & 1 & 1 & 1 & 1 \\
\hline B3 & 0 & 0 & 1 & 1 & 0 & 1 & 0 \\
\hline B4 & 0 & 0 & 0 & 1 & 1 & 1 & 1 \\
\hline B5 & 0 & 0 & 1 & 0 & 1 & 1 & 1 \\
\hline B6 & 0 & 0 & 0 & 0 & 0 & 1 & 0 \\
\hline B7 & 1 & 0 & 1 & 0 & 0 & 1 & 1 \\
\hline
\end{tabular}

Figure 10 Reachability matrix of actors elements

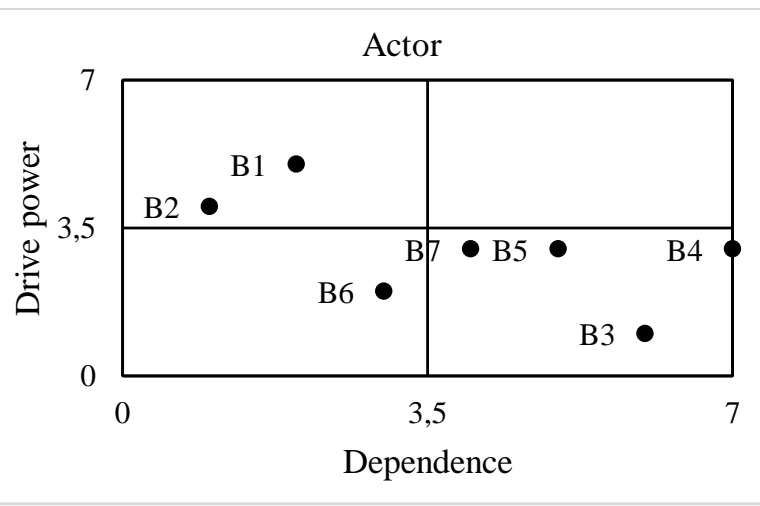

Figure 12 Driver Power-Dependence (DP-D) matrix of actor element 


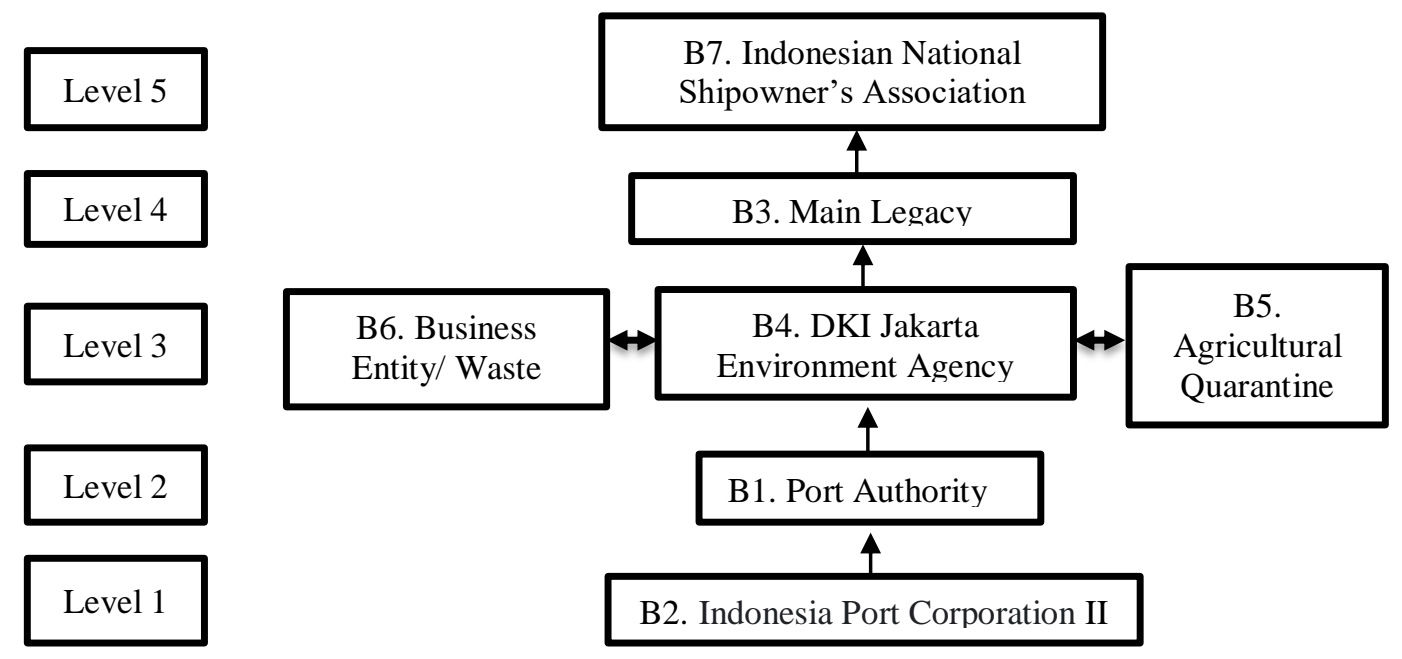

Figure 13 Hierarchy of ship waste management actors

Kesyahbandaran Utama supervises the unloading of waste from ships and provides recommendations for sanctions for those who commit violations. Another actor, namely INSA, is in Weak driver-weak dependent variables (autonomous). Sub elements are not related to the system and have a little relationship but can be strong in the program. INSA based on the Decree of the Minister of Maritime Affairs No. DP.10/7/9 dated 6 September 1967 is an organization as a forum for shipping entrepreneurs who, in this case, are business actors.

\section{Ship Waste Management Strategy}

The right strategy is needed and implemented in preventing the spread of ASF in Tanjung Priok Port. From the ISM results obtained a structural interaction matrix (Figures 14-16). In Figure 17, it can be seen that compiling SOPs and providing PRF is in quadrant IV, which is a Strong drive-weak dependent variable (Independent), i.e. the variable has a significant driving force on the success of the program but is slightly dependent on the program. Even though they are in the same quadrant, compiling SOPs is at level one in the hierarchy (Figure 18). The most important strategy in ship waste management to prevent the spread of ASF is to prepare SOPs, then by providing Port Reception Facilities (PRF). In line with Vaneeckhaute and Fazli (2020), that waste that is usually disposed of at sea can be given pre-treatment on board the ship or at the PRF. It is hoped that the PRF will also be equipped with other facilities, namely waste sorting and treatment areas such as the provision of disinfectants and incinerators, so that the waste that comes out does not contain ASF genetic material.

\begin{tabular}{|c|c|c|c|c|c|c|}
\hline & C1 & C2 & C3 & C4 & C5 & C6 \\
\hline C1 & & A & A & V & A & A \\
\hline C2 & & & V & V & V & V \\
\hline C3 & & & & V & A & A \\
\hline C4 & & & & & A & A \\
\hline C5 & & & & & & A \\
\hline C6 & & & & & & \\
\hline
\end{tabular}

\begin{tabular}{|c|c|c|c|c|c|c|}
\hline & C1 & C2 & C3 & C4 & C5 & C6 \\
\hline C1 & 1 & 0 & 0 & 1 & 0 & 0 \\
\hline C2 & 1 & 1 & 1 & 1 & 1 & 1 \\
\hline C3 & 1 & 0 & 1 & 1 & 0 & 0 \\
\hline C4 & 0 & 0 & 0 & 1 & 0 & 0 \\
\hline C5 & 1 & 0 & 1 & 1 & 1 & 0 \\
\hline C6 & 1 & 0 & 1 & 1 & 1 & 1 \\
\hline
\end{tabular}

Figure 14 Self Structural Interaction Matrix (SSIM) of strategy elements

Figure 15 Reachability matrix elements of strategy elements 


\begin{tabular}{|c|c|c|c|c|c|c|c|c|}
\hline & $\mathrm{C}$ & $\mathrm{C}$ & $\mathrm{C}$ & $\mathrm{C}$ & $\mathrm{C}$ & $\mathrm{C}$ & $\mathrm{D}$ & $\mathrm{R}$ \\
& 1 & 2 & 3 & 4 & 5 & 6 & $\mathrm{P}$ & \\
\hline $\mathrm{C} 1$ & 1 & 0 & 0 & 1 & 0 & 0 & 2 & 5 \\
\hline $\mathrm{C} 2$ & 1 & 1 & 1 & 1 & 1 & 1 & 6 & 1 \\
\hline $\mathrm{C} 3$ & 1 & 0 & 1 & 1 & 0 & 0 & 3 & 4 \\
\hline C4 & 0 & 0 & 0 & 1 & 0 & 0 & 1 & 6 \\
\hline C5 & 1 & 0 & 1 & 1 & 1 & 0 & 4 & 3 \\
\hline C6 & 1 & 0 & 1 & 1 & 1 & 1 & 5 & 2 \\
\hline D & 5 & 1 & 4 & 6 & 3 & 2 & & \\
P & & & & & & & & \\
\hline L & 2 & 6 & 3 & 1 & 4 & 5 & & \\
\hline
\end{tabular}

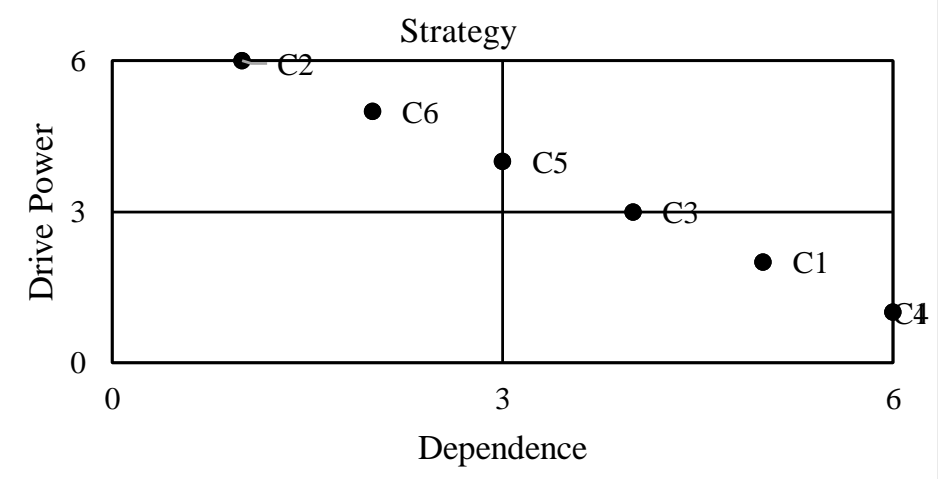

Figure 16 Final reachability matrix elements of strategy elements

Figure 17 Driver Power-Dependence (DP-D) matrix of strategy elements

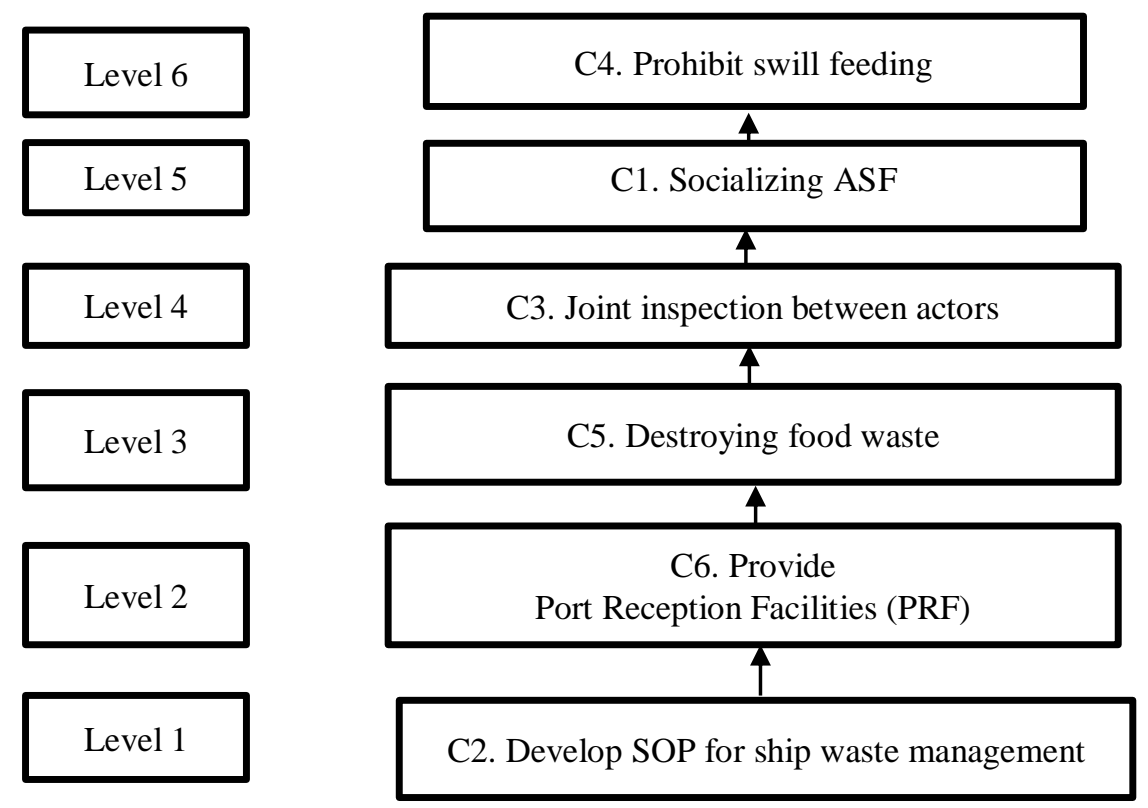

Figure 18 Hierarchy of ship waste management strategies

Strategies to destroy food waste can use ordinary manual combustion or use an incinerator. An incinerator eliminates organic waste through combustion in a controlled and isolated system from the surrounding environment (Sjoerd, 2007). Food waste suspected of containing ASF genetic material is considered infectious waste so that it can be destroyed with an infectious incinerator. The high heating temperature in the incinerator can be inactive the ASF virus properties. Pork can be inactivated by heating at a minimum temperature of $70^{\circ} \mathrm{C}$ for a minimum of 30 minutes (Alcrudo et al., 2019), while in the product Pigs by heating commercially sterilized at $121^{\circ} \mathrm{C}$ for 3 minutes, minimum steam pressure of $2 \mathrm{psi}$, the swill can be inactivated by heating at $90^{\circ} \mathrm{C}$ for a minimum of 60 minutes with continuous stirring or by heating commercial sterilizers at $121^{\circ} \mathrm{C}$ for a minimum of 10 minutes, pressure 3 bar (OIE, 2019)

Inspection between actors is included in the Strong driver-strongly dependent variables (Linkage); each action on variable impacts the other, and feedback can magnify the effect. Inspection is a thorough, direct examination of the implementation of regulations, duties, and so on (KBBI, 2019). The following strategy is to socialize ASF and prohibit swill feeding. Socialization is a process that helps members of society learn and adapt to the way of life, the way of thinking of the group so that they can play a role and function in the group (Buhler, 1980). ASF transmission can be through swill feeding produced by aircraft and ships sailing between 
countries or regions (Alcrudo et al., 2019). Food waste is widely used as animal feed because the price is low or even unpaid. It is known that in the Bantar Gebang TPST, there are no pig farms in the vicinity.

\section{CONCLUSION}

In the management of ship samples to prevent the spread of ASF, the most influencing constraint is the availability of Standard Operating Procedures (SOP), the actor who plays the most role is Indonesia Port Corporation II, and the most important strategy is to develop an integrated SOP for ship waste management.

\section{REFERENCES}

[BPS] Badan Pusat Statistik. 2019. Populasi Babi menurut Provinsi (Ekor), 2018- 2020 [Internet]. [Downloaded 2021 Jan 24]. Available at: https://www.bps.go.id/indicator/24/474/1/ populasi-babimenurut-provinsi.html.

[CFSPH] The Center for Food Security \& Public Health. 2019. Classical Swine Fever [Internet]. [Downloaded 2020 Jan 24]. Available at: http://www.cfsph.iastate. edu/Factsheets/pdfs/african_swine_fever.pdf.

[Dirjenak] Direktorat Jenderal Peternakan dan Kesehatan Hewan. 2019. Peraturan Menteri Pertanian No. 820/KPTS/PK.320M/12/2019 tentang Pernyataan Wabah Penyakit Demam Babi Afrika (African Swine Fever). Jakarta (ID): Dirjenak.

[EFSA] European Food Safety Authority. 2014. Scientific Opinion on African swine fever EFSA Panel on Animal Health and Welfare (AHAW) [Internet]. [Downloaded 2019 Sep 27]. Available at: https://efsa.onlinelibrary.wiley.com/doi/epdf/ 10.2903/j.efsa.2014.3628.

[EMSA] European Maritime Safety Agency. 2017. The Management of Shipgenerated Waste On-Board Ships [Internet]. [Downloaded 2020 Jan 24]. Available at: http://www.EMSA.europa.eu/news-a-presscentre/externalnews/item/2925-the-management-of-ship-generated-waste on-boardships.html.

[FAO] Food and Agriculture Organization. 2019. One Year On, Close to 5 Million Pigs Lost to Asia's Swine Fever Outbreak [Internet]. [Downloaded 2020 Feb 01]. Available at: http://www.fao.org/asiapacific/news/detail-events/en/c/1204584/.

[IMO] International Maritime Organization. 2006. Marpol Consolidation 2006: Annex V-Regulations for the Prevention of Pollution by Garbage from Ships [Internet]. [Downloaded 2020 Jan 24]. Available at: http://www.marpoltraining.com/MMSKOREAN/ MARPOL/Annex V/index.htm.

[KBBI] Badan Pengembangan dan Pembinaan Bahasa. 2019. KBBI Daring [Internet]. [Downloaded 2021 Aug 22] Available at: https:// https://kbbi.kemdikbud.go.id/.

[KemenLH] Kementerian Negara Lingkungan Hidup. 2009. Peraturan Menteri Nomor 05 Tahun 2009 Tentang Pengelolaan Limbah Di Pelabuhan [Internet]. [Downloaded 2020 Oct 08]. Available at: https://luk.staff.ugm.ac.id/atur/sda/PermenLH52009LimbahDiPelabuhan.pdf.

[KemenMaritim] Kementerian Maritim. 1967. Keputusan Menteri Maritim No.DP/10/7/9 tentang Indonesia Shipowner's Association (INSA) [Internet]. [Downloaded 2020 Apr 08] Available at: https://insa.or.id/regulation-internal/anggaran-dasar-insa-2015-2019/.

[MARPOL 73/78] International Maritime Organization. 1978. Marpol 73/78 Annex V tentang Pencegahan Pencemaran yang Diakibatkan oleh Sampah dari Kapal [Internet]. [Downloaded 2020 Jan 24]. Available at: https://jdih.setkab.go.id/PUUdoc/17492/Perpres_No_29_2012Lampiran\%20V\%20terjem ahan.pdf.

[OIE] World Organization for Animal Health. 2019. Terrestrial Animal Health Code [Internet]. [Downloaded 2020 Jan 22]. Available at: https://www.oie.int/fileadmin/Home/eng/Health_standards/tahm/ 3.08.01_ ASF. pdf.

[Pelindo] PT Pelabuhan Indonesia II (Persero) Cabang Tanjung Priok. 2019. Jumlah Frekuensi Kapal Laut yang Bersandar di Pelabuhan Tanjung Priok Tahun 2019. Jakarta (ID): Pelindo. 
[Pelindo] PT Pelabuhan Indonesia II (Persero) Cabang Tanjung Priok. 2020. Jumlah Frekuensi Kapal Laut yang Bersandar di Pelabuhan Tanjung Priok Bulan Januari-Mei 2020. Jakarta (ID): Pelindo.

Alcrudo BD, Falco JR, Raizman E, Dietze K. 2019. Transboundary spread of pig diseases: the Role of international trade and travel. BMC Veterinary Research. 15(1): 1-14. doi: https://doi.org/10.1186/s12917-019-1800-5.

Arimurti PI, Basri C, Lukman DW. 2021. Deteksi virus african swine fever dari sampah makanan kapal laut internasional di Pelabuhan Tanjung Priok. Acta Veteriner Indonesia. 9(2): 111-119.

Atmoko T. 2011. Standar Operasional Prosedur (SOP) dan Akuntabilitas Kinerja Instansi Pemerintah. Bandung (ID): Unpad.

Buhler C. 1980. Practishe Kinder Psychologie [Internet]. Boston (US): Hougton Mifflin,Co. [2021 Jan 11]. Available at: https://www.researchgate.net/search.Search.html?type=publication\&query=Buhler\%20C. \%201980.\% 20Practishe\%20Kinder\%20Psychologie.

Defra. 2007. Incinerator of Municipal Solid Waste, Department for Environment Food and Rural Affairs [Internet]. [Downloaded 2021 Feb 01]. Available at: https://www.gov.uk/government/publications/incin eration-of-municipal-solid-waste.

Eriyatno. 1996. Ilmu Sistem: Meningkatkan Mutu dan Efektivitas Manajemen. Jilid I. Edisi Ketiga. Jakarta (ID): Rineka.

Indonesian Government. 2008. Undang-Undang Nomor 18 Tahun 2008 tentang Pengelolaan Sampah [Internet]. [Downloaded 2020 Sep 20]. Available at: https://pelayanan.jakarta.go.id/download/regulasi /undang-undang-nomor-18-tahun-2008-tentang-pengelolaan-sampah.pdf.

Indonesian Government. 2019. Undang-Undang Nomor 21 Tahun 2019 tentang Karantina Hewan, Ikan dan Tumbuhan [Internet]. [Downloaded 2020 Feb 01]. Available at: https://sipuu.setkab.go.id/PUUdoc/175 977/UU_Nomor_21_Tahun_2019.pdf.

Santoso PBK, Widiatmaka, Sabiham S, Machfud M, Rusastra IW. 2017. Analisis pola konversi lahan sawah dan struktur hubungan penyebab dan pencegahannya (studi kasus Kabupaten Subang, Provinsi Jawa Barat). Journal of Natural Resources. 7: 184-194. doi: 10.29244/JPSL.7.2.184-194.

Sjoerd N. 2007. Plastic Waste Insulation for High Altitude Areas Application in Houses, Greenhouses and Biogas Reactors, Kathmandu [Internet]. [Downloaded 2020 Oct 21]. Available at: https://www.researchgate.net/search.Search.html?type=researcher\&query=Sjoerd\%20Nienhuys.

Vaneeckhaute C, Fazli A. 2020. Management of ship-generated food waste and sewage on the Baltic Sea. Waste Management Journal. 102: 12-20.

Warfield J. 2005. Developing interconnection matrices in structural modelling. IEEE Transactions on Systems, Man and Cybernetics. 4(1): 81-87. 